Relations industrielles

Industrial Relations

\title{
The Future of Work, by John Wilkes, Ed., Sydney, G. Allen and Unwin, Australia Institute of Political Science, 1981, 164 pp., ISBN 0-86861-283-9.
}

\section{Alexander J. Matejko}

Volume 38, numéro 3, 1983

URI : https://id.erudit.org/iderudit/029395ar

DOI : https://doi.org/10.7202/029395ar

Aller au sommaire du numéro

Éditeur(s)

Département des relations industrielles de l'Université Laval

ISSN

0034-379X (imprimé)

1703-8138 (numérique)

Découvrir la revue

Citer ce compte rendu

Matejko, A. J. (1983). Compte rendu de [The Future of Work, by John Wilkes, Ed., Sydney, G. Allen and Unwin, Australia Institute of Political Science, 1981, 164 pp., ISBN 0-86861-283-9.] Relations industrielles / Industrial Relations, 38(3), 689-689. https://doi.org/10.7202/029395ar

Tous droits réservés (C) Département des relations industrielles de l'Université Laval, 1983
Ce document est protégé par la loi sur le droit d'auteur. L’utilisation des services d'Érudit (y compris la reproduction) est assujettie à sa politique d'utilisation que vous pouvez consulter en ligne.

https://apropos.erudit.org/fr/usagers/politique-dutilisation/ 
The Future of Work, by John Wilkes, Ed., Sydney, G. Allen and Unwin, Australia Institute of Political Science, 1981, 164 pp., ISBN 0-86861-283-9

People still gain their self-respect and sense of worth mainly from work but what to do when there are not enough jobs around? The growth of unemployment in Australia, especially among young unskilled people, married women/especially migrants/ and people over 45 has created several problems. There is a growing number of chronically unemployed. The spread of part-time employment is only a substitute; for the employers it is convenient to depend on the labour power which is cheaper. Women as in other countries earn in Australia considerably less than men. Due to all these factors, there is an increase in levels of inequality on the society and the lack of self-esteem by those not in the paid work-force.

It is clear from data and insights presented in the book that the chronically unemployed in Australia generally want work badly and understand perfectly well the economic, social, psychological and status rewards associated with paid employment. Older people are reluctant to leave the workforce. Many persons employed part time would be happy to gain a full time employment. To move outside the remunerative work is a personal drama of many people and the situation in this respect has little chance to change in the future. The leisure society does not go well together with the consumer society as long as in order to have leisure it is necessary to earn enough. The progressing division of the population into those in the paid work-force and those unable to participate in employment is a fact of great significance. The great majority of the Australian population are doing quite well but the unemployed minority does not have much chance to improve their situation, especially when facing the unavoidable technological progress. People who are economically stable are not in favour of an additional taxation or expensive government initiatives to assist the minority. On the other hand, the economic recovery of the whole economy is frustrated by the anti-competitive practices dictated by the vested interests of various sectional groups.

Alexander J. MATEJKO

\section{The University of Alberta}

Qualité de vie au travail: anti-stress et créativité, par Pierre R. Turcotte, Montréal, Agences d'Arc, 1982, 184 pp., ISBN 2-89022-046-x

Cet ouvrage a pour objectif de rapprocher trois concepts fort populaires: la Q.V.T., le stress et la créativité. Même si les deux premiers ont déjà été mis ensemble, $\mathrm{y}$ ajouter le troisième fait preuve d'originalité et même d'un certain courage. Or l'auteur s'en tire fort élégamment et l'exercice est digne de mérite.

Les deux premiers chapitres décrivent la Q.V.T.: bref rappel historique et situation actuelle (chap. 1); définition et mesures (chap. 2 ). Les chapitres 3 et 4 définissent le stress par ses sources, ses variables modératrices et ses conséquences. Le chapitre 5 , concerne tout le problème de la créativité alors que le chapitre suivant (le plus important) présente la vision de l'auteur sur "la qualité de vie au travail: une synthèse du stress et de la créativité». L'objectif du volume est atteint dans ce chapitre. Enfin, le dernier chapitre décrit différents programmes d'amélioration de la Q.V.T.

En général, l'ouvrage de Turcotte est très bien présenté et sa lecture en est intéressante d'un bout à l'autre.

Chaque chapitre est précédé d'un énoncé très clair d'objectif et se termine par une conclusion-résumé. Les synthèses qui foisonnent dans ce travail en font un ouvrage de référence intéressant. En effet, qu'il s'agisse de concepts aussi complexes que la Q.V.T., le stress, la créativité, de l'évolution historique en G.R.H., des inter-relations entre ces con- 